薄鋼板の跳弾痕を用いた発射弾丸, 弾道の推定に関する研究

戸山恭平，平島昭雄，竹下尚紀，西嶋靖治

福岡県警察科学捜査研究所

\%812-8576 福岡市博多区東公園 7 番 7 号

\title{
Estimate of Type and Trajectory of the Fired Bullet from the Analysis of the Ricochet Mark on a Thin Steel Plate
}

\author{
Kyohei Toyama, Akio Hirashima, Hisanori Takeshita and Yasuharu Nishijima \\ Forensic Science Laboratory, Fukuoka Prefectural Police H.Q. \\ 7-7 Higashikoen, Hakata-ku, Fukuoka 812-8576, Japan
}

(Received 20 April 2012; accepted 30 July 2012)

In order to estimate type and trajectory of the fired bullet from the analysis of the ricochet mark, we carried out the gunfire test against the inclined target. $1.2 \mathrm{~mm}$ thin steel plates were used as intermediate targets in this study. The following are types of cartridges which were used: 25 AUTO., 32 AUTO., $7.62 \mathrm{~mm}$ Tokarev, 380 AUTO., 38 SPL. (FMC), 38 SPL. (LRN), 9 mm Luger and 45 AUTO.. The target was put in a wooden frame. The angle of incidence was changed by rotating the wooden frame.

We could classify the deformation morphology on the thin steel plate into 4 patterns: Ricochet mark without the crack (Type 1), Ricochet mark with the small crack (Type 2), Ricochet mark with the large crack (Type 3), Penetration (Type 4). Metal from the bullet surface was left on the surface of the target. It was thought that the crack in the edge of the ricochet mark (Type 2 or 3 ) was caused by the friction arising from the rifling rotation of the fired bullet. The length of the ricochet mark in the longitudinal direction $L$ increases with increase of the kinetic energy of the bullet $E$. The value of $L$ was relative to the kinetic energy resolved into the horizontal component of the velocity $\operatorname{E}_{\cos ^{2}} \theta_{\mathrm{i}}\left(\theta_{\mathrm{i}}\right.$ : the angle of incidence). Except for 380 AUTO. and 38 SPL., the value of $L$ was almost independent of $E$ and $E \cos ^{2} \theta_{\mathrm{i}}$ respectively. The ratio of the angle of ricochet $\theta_{\mathrm{r}}$ to the angle of incidence $\theta_{\mathrm{i}}$ was around 1 to 2 . Therefore, caliber and type of a fired bullet and the trajectory can be determined from the analysis of the ricochet mark and the contour when the bullet is fired into a $1.2 \mathrm{~mm}$ thin steel plate.

Key words: Ricochet, Ricochet mark, the Angle of incidence, the Angle of ricochet 


\section{諸 言}

近年, 全国的に暴力団の排除に関する条例が施行 され，社会にお打る暴力団排除の気運が盛り上がる 中，警察も総力を挙げて暴力団犯罪の撲滅に向けた 取り組みを強化している。そのような現状におい て, 特に暴力団が絡む拳銃発砲事件については, 社 会の安全 ·安心の確保のために事件の早期解決が求 められている.

従来，拳銃発砲事件では，発射弾丸や打ち殼薬き ょうから銃種や弾丸種類を推定し，発射弾丸による 破孔から弾道を計測している。しかし，発射弾丸が 車両などの鉄鋼製品に衝突して跳弾した場合，発射 弾丸の発見が困難になる場合が多く, 銃種や弾丸種 類が不明となることがあった。また，跳弾痕から は, 弾道の計測ができなかった。

これまで, 水面, 地面, 鋼板, コンクリート, ま たは石こうボードなどで発生する弾丸や散弾の跳弾 に関する研究が行われてきた ${ }^{1-15)}$. 鋼板に対する跳 弾については, 厚さ $1 / 16$ インチおよび $1 / 8$ インチ の鋼板に対して, 0.22 Long Rifle, 38 SPL. および 45 AUTO.の三種類の実包を試射した研究2)，厚さ $9.5 \mathrm{~mm}$ の鋼板に散弾（12番，00 buckshot）を試身 した研究6)，厚さ $1.5 \mathrm{~mm}$ 抢よび $6.0 \mathrm{~mm}$ の鋼板に 45 AUTO. を試射した研究13), そして, $6.0 \mathrm{~mm}$ の鋼 板に 9 mm Luger, 45 AUTO. 抢よび357 Magnum の 三種類の実包を試射した研究14)など様々な実験条件 で研究が行われている。 また, 車両の跳弾痕につい て検査した事例も報告されている11,12). しかし，こ れらの研究の結果は, 実際の拳銃発砲事件にそのま ま適用できるものは少なかった。

そこで, 本研究では, 発射弾丸が鉄鋼製品で跳弾 した発砲事件において, 発射弾丸の実包の種類や弾 道を推定するために, 発砲事件でよく使用される実 包および一般的に使用される薄鋼板を用いて跳弾を ともなう試射試験を行い, 形成された跳弾痕から発 射弾丸の実包の種類や弾道を推定する方法について 研究を行った.
Table 1 Chemical composition of SPCC (\%).

\begin{tabular}{ccccc}
\hline $\mathrm{C}$ & $\mathrm{Si}$ & $\mathrm{Mn}$ & $\mathrm{P}$ & $\mathrm{S}$ \\
\hline 0.0189 & 0.002 & 0.177 & 0.0083 & 0.0047 \\
\hline
\end{tabular}

Table 2 Mechanical property.

\begin{tabular}{ccc}
\hline$\sigma_{\mathrm{y}}(\mathrm{MPa})$ & $\sigma_{\mathrm{b}}(\mathrm{MPa})$ & Elongation $(\%)$ \\
\hline 188 & 313 & 48 \\
\hline
\end{tabular}

$\sigma_{\mathrm{y}}:$ Yield stress, $\sigma_{\mathrm{b}}$ : Tensile strength

\section{材料および方法}

\section{1. 被射体}

標的となる薄鋼板には，一般的に使用されている 厚さ $1.2 \mathrm{~mm}$ の冷間圧延鋼板 SPCC $(300 \times 300 \mathrm{~mm})$ を用いた。

Table 1 に化学成分および Table 2 に機械的性質 を示す.

\section{2. 試射用実包および試射用拳銃}

Fig. 1 および Table 3 に試射に用いた実包の種類 を示す。試射用実包には，レミントン銃器会社製の 25 AUTO., 32 AUTO., 380 AUTO., 9 mm Luger, 45 AUTO.，中国第11製造所製の7.62 mm Tokarev お よび警察官用執行実包 38 SPL.の 7 種類の被甲弾 (FMC: Full Metal Case) を用い,さらに，レミン トン銃器会社製の 38 SPL.の硬鉛弾（LRN： Lead Round Nose）を用いた。警察官用執行実包38 SPL. を除き，いずれも発砲事件でよく使用される弾丸で ある。

Table 3 に試射用拳銃を示す．試射用拳銃につい ては，いずれも当研究所所有の適合拳銃を用いた. 38 SPL.については，銃種による跳弾への影響を調 べるために，口径 0.38 インチ スミスアンドウエッ ソン $(\mathrm{S} \& \mathrm{~W}) \mathrm{M} 10$ および同口径スカイヤーズ ビン ガム ディテクティブ チーフの 2 種類を試射試験に 用いた。

\section{3. 試射試験}

Fig. 2 に跳弾をともなう試射試験の方法を示す. 試射試験の標的となる薄鋼板を発射弾丸の弾道方向 に対して傾斜させて設置した。薄鋼板の四辺を正方 型の木枠で支持し，薄鋼板の四辺は，自由端とし 


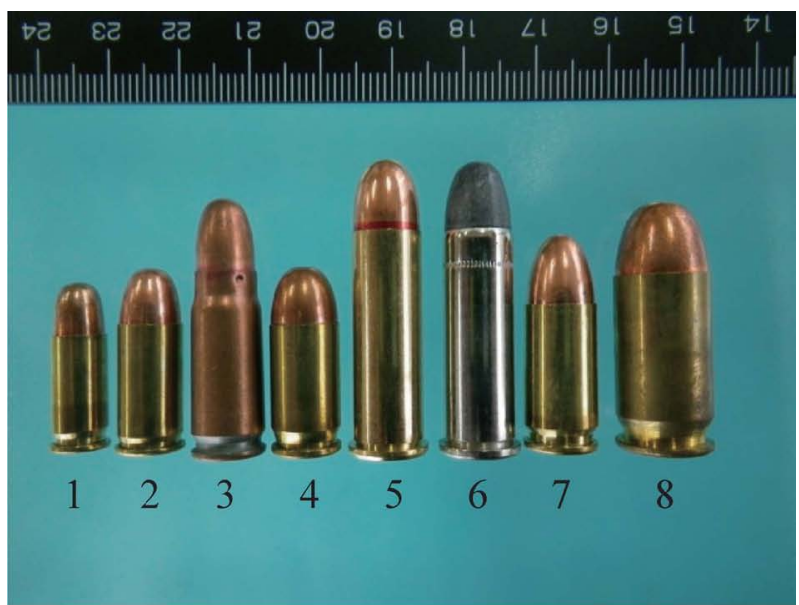

(a) Cartridges

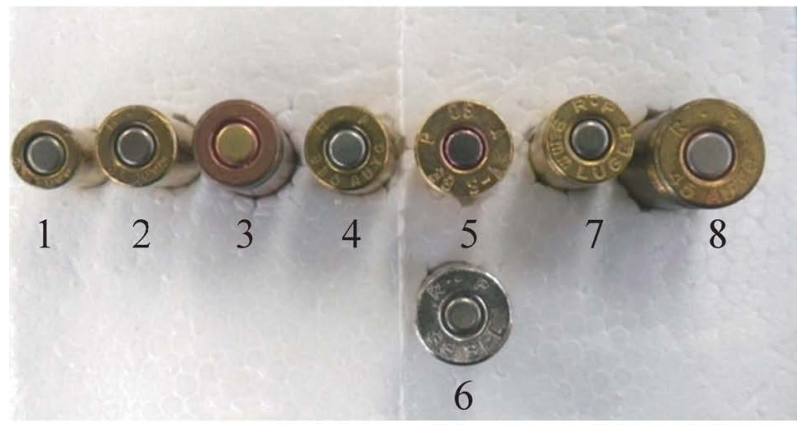

(b) Headstamp

1) 25 AUTO., 2) 32 AUTO.,

3) $7.62 \mathrm{~mm}$ Tokarev, 4) 380 AUTO.,

5) 38 SPL. (FMC), 6) 38 SPL. (LRN),

7) $9 \mathrm{~mm}$ Luger, 8) 45 AUTO.

Fig. 1 Cartridges.
た. 入射角 $\theta_{\mathrm{i}}$ は, 水平面上に抢いて, 発射弾丸の 進行方向と薄鋼板のなす角度とし, 同様に, 反射角 $\theta_{\mathrm{r}}$ は, 跳弾した発射弾丸の進行方向と薄鋼板のな す角度とした。

入射角 $\theta_{\mathrm{i}}$ は，水平面上に打いて，銃口から薄鋼 板上に定めた 2 点 $\mathrm{A}, \mathrm{C}$ （間隔 $150 \mathrm{~mm}$ ） までの距離 OA，OCをそれぞれ計測し，三角形 OACに打ける 余弦定理を用いて式 $(\mathrm{a}-1)$ に示すと打り， $\angle \mathrm{OAC}$

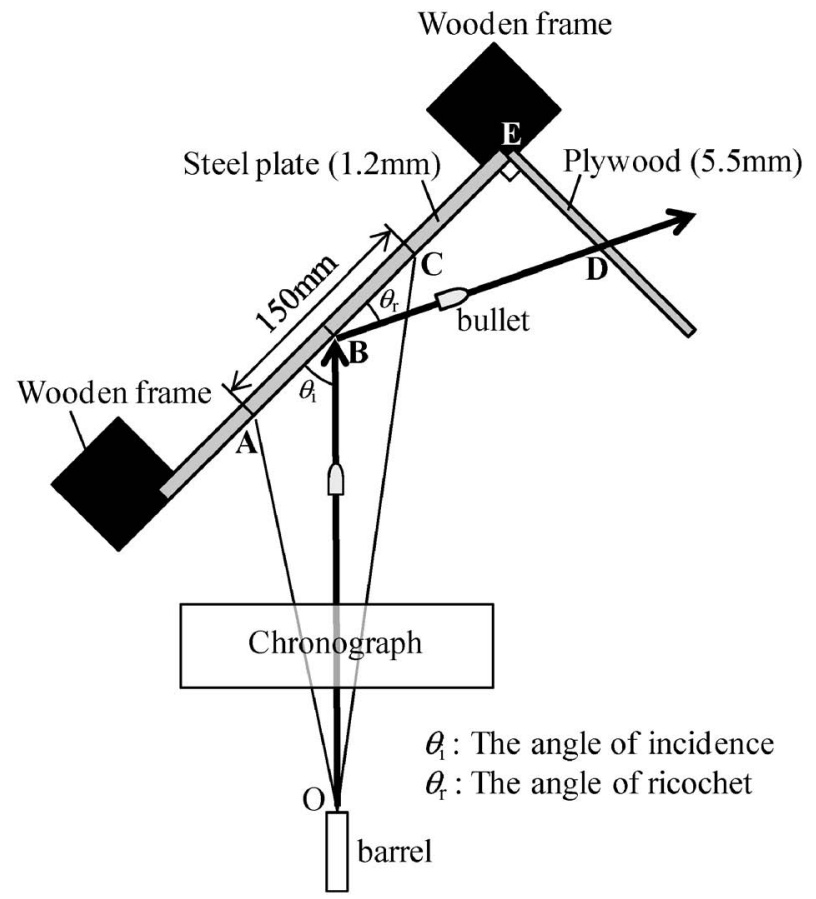

Fig. 2 Schematic illustration of the gunfire test.

Table 3 Cartridges and pistols.

\begin{tabular}{|c|c|c|c|c|c|c|}
\hline & Cartridge & $\underset{(\mathrm{g})}{\text { weight }}$ & $\begin{array}{l}\text { Bullet } \\
\text { diameter } \\
(\mathrm{mm})\end{array}$ & Type & Pistol & $\begin{array}{l}\text { Rifling } \\
\text { class }\end{array}$ \\
\hline 1 & 25 AUTO. & 3.2 & 6.4 & FMC & Cal. $6.35 \mathrm{~mm}$ Walther Auto. Mod. TPH & $6-\mathrm{R}$ \\
\hline 2 & 32 AUTO. & 4.5 & 7.9 & FMC & Cal. 0.32 inches Colt Auto. Pocket Mod. & $6-\mathrm{L}$ \\
\hline 3 & $7.62 \mathrm{~mm}$ Tokarev & 5.5 & 7.7 & FMC & Cal. $7.62 \mathrm{~mm}$ Tokarev Auto. & $4-\mathrm{R}$ \\
\hline 4 & 380 AUTO. & 6.2 & 9.1 & FMC & Cal. 0.380 inches Titan Auto. & $6-\mathrm{R}$ \\
\hline \multirow[b]{2}{*}{5} & \multirow[b]{2}{*}{38 SPL. } & \multirow[b]{2}{*}{10.2} & \multirow[b]{2}{*}{9.1} & \multirow[b]{2}{*}{ FMC } & Cal. 0.38 inches S\&W Rev. Mod. 10 & $5-\mathrm{R}$ \\
\hline & & & & & $\begin{array}{l}\text { Cal. 0.38 inches Squires Bingham Rev. Detective } \\
\text { Chief }\end{array}$ & 6-L \\
\hline 6 & 38 SPL. & 10.2 & 9.1 & LRN & Cal. 0.38 inches S\&W Rev. Mod. 10 & $5-\mathrm{R}$ \\
\hline 7 & $9 \mathrm{~mm}$ Luger & 8.1 & 9.1 & FMC & Cal. 0.38 inches Colt Commander Auto. & $6-\mathrm{L}$ \\
\hline 8 & 45 AUTO. & 14.9 & 11.4 & FMC & Cal. 0.45 inches Colt Commander Auto. & 6-L \\
\hline
\end{tabular}


を求め, さらに, 銃口から弾痕の中心 $\mathrm{B}$ なでの距 離 $\mathrm{OB}$ を計測し, 三角形 $\mathrm{OAB}$ に打ける正弦定理を 用いて式 $(a-2)$ に示すと抢り算出した.

$$
\begin{aligned}
& \angle \mathrm{OAC}=\cos ^{-1}\left(\frac{\mathrm{OA}^{2}+\mathrm{AC}^{2}-\mathrm{OC}^{2}}{2 \mathrm{OA} \cdot \mathrm{AC}}\right) \\
& \theta_{\mathrm{i}}=\sin ^{-1}\left(\frac{\mathrm{OA}}{\mathrm{OB}}\right) \sin \angle \mathrm{OAC}
\end{aligned}
$$

距離の計測には, ライカ製 レーザー距離計 Leica DISTO $^{\mathrm{TM}}$ D8 を用いた。

なお, 入射角 $\theta_{\mathrm{i}}$ が $10^{\circ}$ 未満の実験では, 上記手法 による計測が困難だったため, 分度器を用いて木枠 の位置を設定し，入射角 $\theta_{\mathrm{i}}$ を決定した。

反射角 $\theta_{\mathrm{r}}$ は, 跳弾方向側に薄鋼板に対して垂直 に設置した厚さ5.5 mm の合板に形成される貫通孔 の位置から式(a-3)を用いて算出した.

$$
\theta_{\mathrm{r}}=\tan ^{-1}\left(\frac{\mathrm{DE}}{\mathrm{BE}}\right)
$$

試射は, 薄鋼板から約 $5 \mathrm{~m}$ 離れた位置から行 い, 弾速は，薄鋼板に衝突する直前に設置した光電 式弾速測定器を用いて計測した。跳弾した発射弾丸 については, 回収した。

\section{1. 試射試験結果}

\section{結果および考察}

\section{(1) 薄鋼板の変形形態}

Fig. 3, 4 に被甲弾による試射試験後の薄鋼板の変 形形態を示し, Fig. 5 に硬鉛弾による試射試験後の 薄鋼板の変形形態を示す. 本研究では, 試射試験後 の薄鋼板の変形形態を,

(1) Type 1: 亀裂の形成されない跳弾痕

(2) Type 2: 微小亀裂が形成された跳弾痕

(3) Type 3: 開口亀裂が形成された跳弾痕

(4) Type $4:$ 貫通孔

の 4 種類に分類した．入射角 $\theta_{\mathrm{i}}$ が大きくなるにつ れて, 跳弾痕は, Type 1 から Type 3 へ遷移してい き, 最終的に跳弾痕加貫通孔（Type 4) に变化し た。

Fig. 3 (a)に示すとおり，25 AUTO.については， 薄鋼板に対して垂直方向 $\left(\theta_{\mathrm{i}}=90^{\circ}\right)$ から試射して も発射弾丸が貫通せず，薄鋼板に亀裂が形成されな かった。したがって，跳弾痕は，いずれも Type 1
に分類された.

Fig. 3(c)に示すとおり， $7.62 \mathrm{~mm}$ Tokarev につい ては，他の発射弾丸に打ける試射試験結果に比べ, 薄鋼板の変形形態が著しかった．Type 1 の跳弾痕 は，入射角 $\theta_{\mathrm{i}}$ が約 $6^{\circ}$ の結果のみに見られ，その他 の跳弾痕は Type 3 に分類された.

(2) 跳弾痕の表面

Fig. 3 Fig. 5 の薄鋼板の変形形態に示すとお り，被甲弾によって形成された跳弾痕と硬鉛弾によ って形成された跳弾痕とを比較すると, 被甲弾によ って形成された跳弾痕には, 薄鋼板と発射弾丸との 接触部に銅色ようの固着物が見られ，硬鉛弾によっ て形成された跳弾痕には，薄鋼板と発射弾丸との接 触部に鉛の薄片の固着が見られた。

（3）跳弾痕に形成された亀裂

Fig. 3, 4 の被甲弾による薄鋼板の変形形態に示す とおり，被甲弾による跳弾痕のうち，Type 2 に見 られた微小亀裂は，薄鋼板と発射弾丸との接触部側 端を起点に形成されていた。 また，Type 3 に見ら れた開口亀裂も同様に，薄鋼板と発射弾丸との接触 部側端を起点に形成されていた。したがって， Type 3 の開口亀裂は, Type 2 の微小亀裂が進展 し，開口した結果，形成されたものと考えられた。

Fig. 4(h)の Type 3 (24 deg.) と Type 4 (25 deg.) における薄鋼板の変形形態を比較すると, Type 3 の跳弾側の亀裂先端部は, 鋭利な形状であったが, Type 4 になると, 亀裂先端は, 円弧状の形状にな っていた。この違いは，発射弾丸による貫通の有無 が原因であると考えられた。

また, Type 2, 3 の跳弾痕に形成された亀裂は, スミスアンドウエッソン（38 SPL.）やタイタン (380 AUTO.) のように，銃口の腔旋が右回転の場 合, 発射弾丸の進行方向に対して接触部側端右側に 形成され，コルト（32 AUTO., 9 mm Luger および 45 AUTO.) やスカイヤーズビンガム（38 SPL.) のように，銃口の腔旋が左回転の場合，発射弾丸の 進行方向に対して接触部側端左側に形成された。し たがって，被甲弾の場合，跳弾痕に形成された亀裂 は，発射弾丸の旋回方向の影響を大きく受けると考 えられた、ただし，跳弾痕には，腔旋痕やその幅な ぞ，さらに拳銃を特定できる痕跡が見られなかっ 
Trajectory of bullet

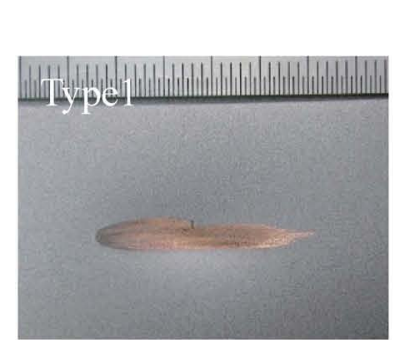

11(deg.)

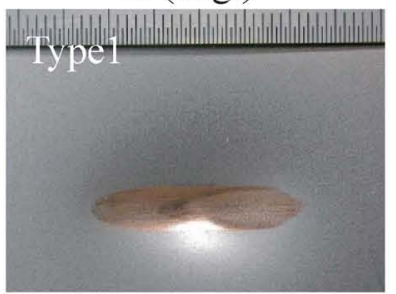

22(deg.)
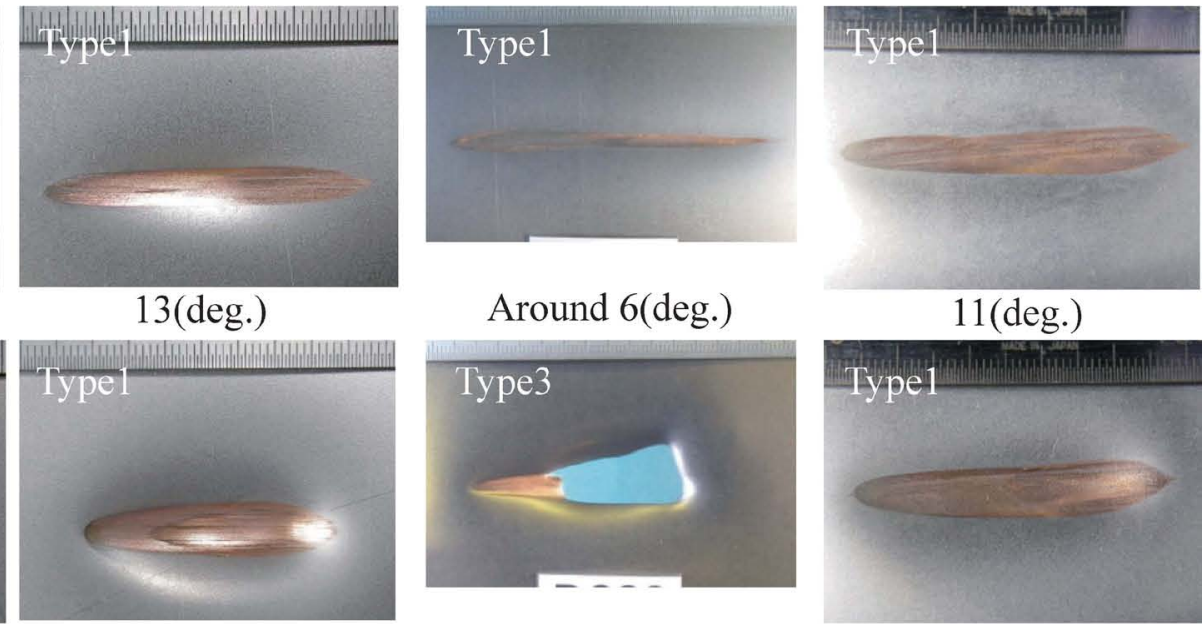

\section{1(deg.)}
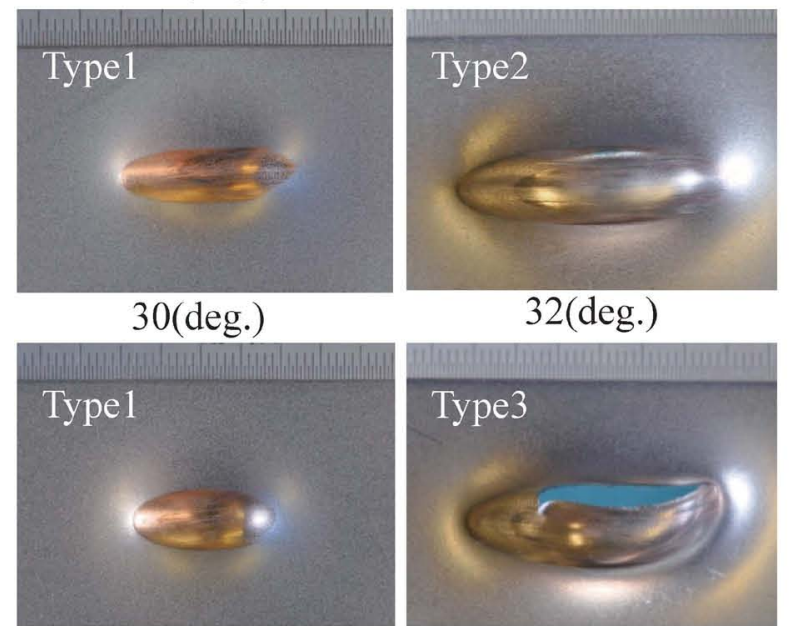

\section{2(deg.)}
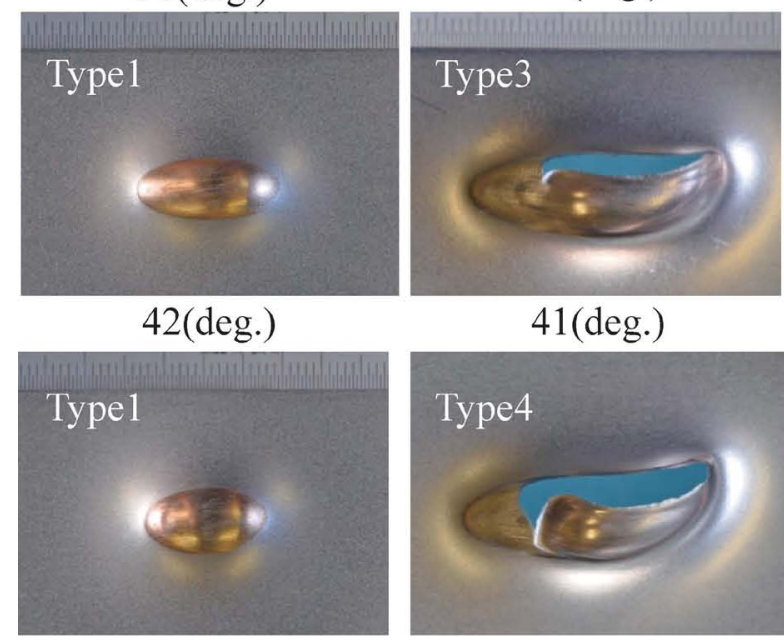

48(deg.)

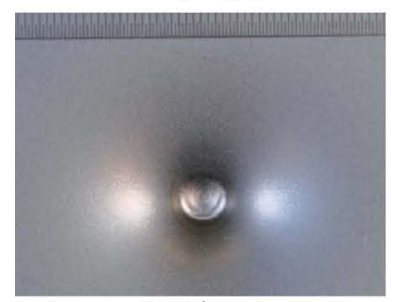

90(deg.)
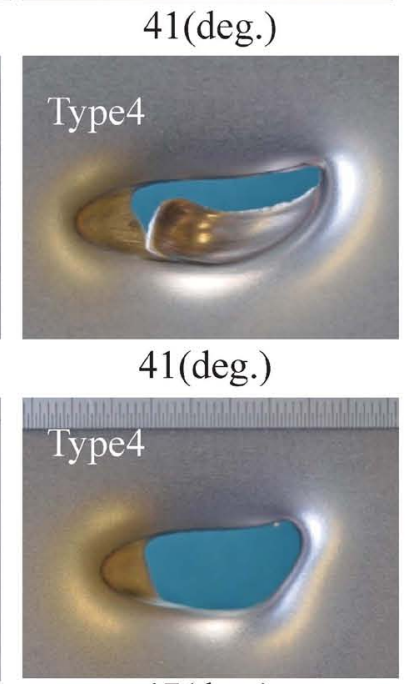

(a) 25 AUTO.

Around 6(deg.)

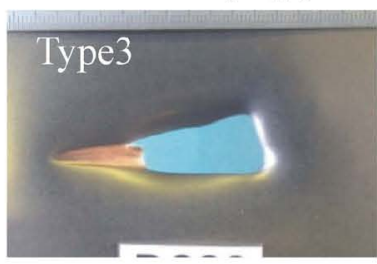

Around 9(deg.)
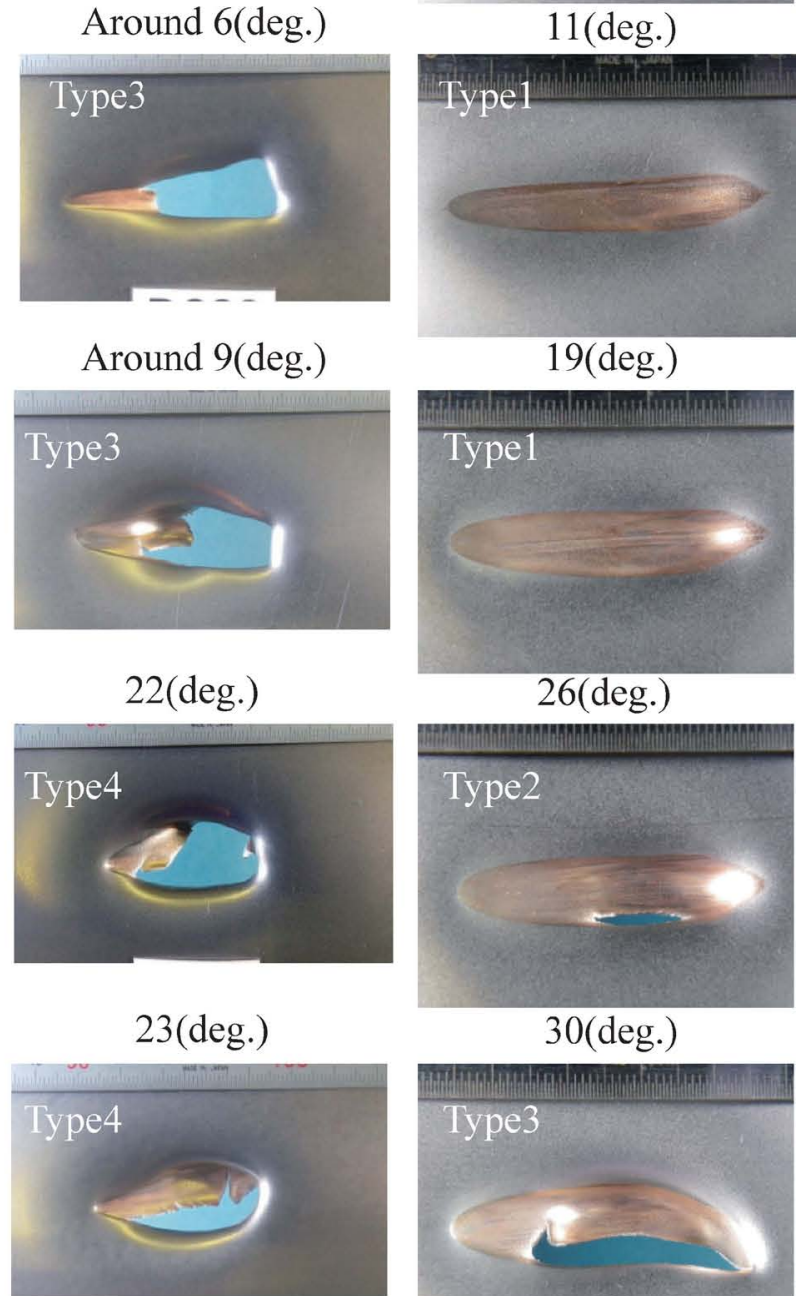

19(deg.)

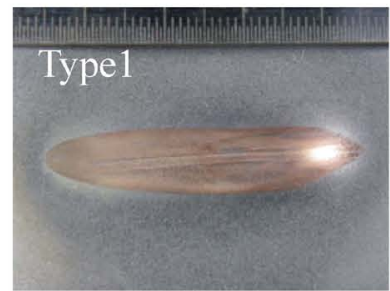

26(deg.)
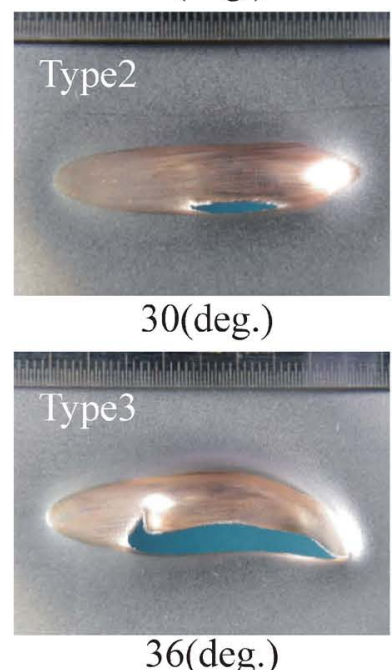

26(deg.)

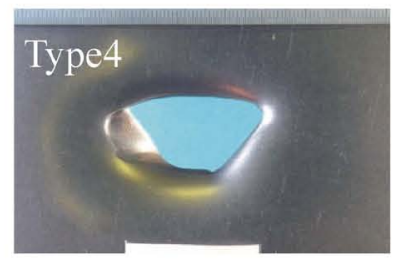

31(deg.)

(c) $7.62 \mathrm{~mm}$ Tokarev

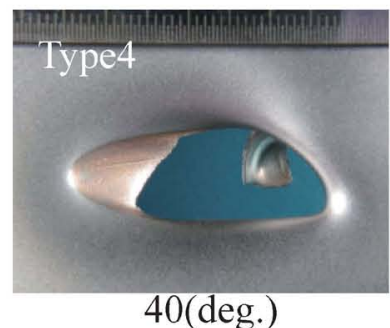

(d) 380 AUTO.(FMC)

Fig. 3 Deformation of the thin steel plate after impact of a jacketed bullet, (a)-(d). 
Trajectory of bullet

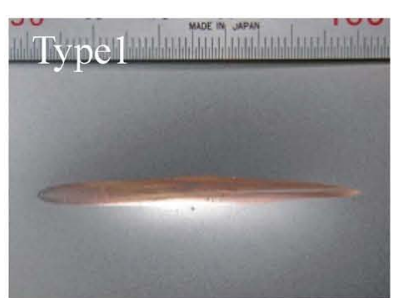

1 (deg.)

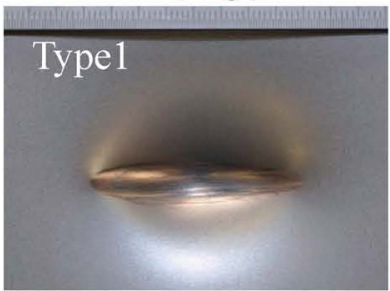

31(deg.)
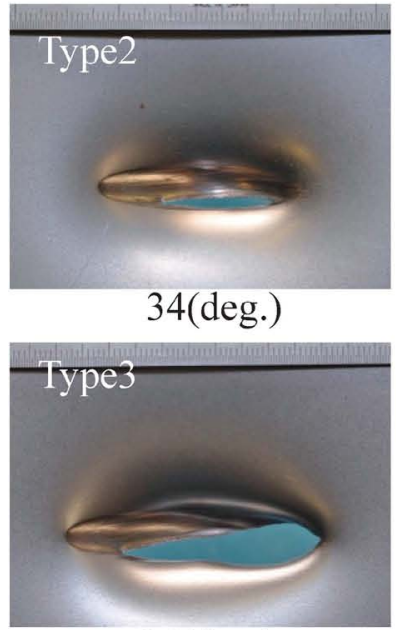

36(deg.)

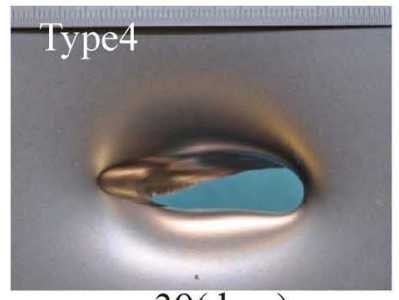

39(deg.)

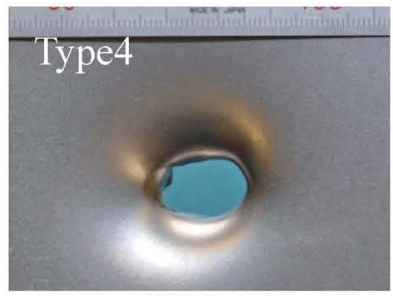

53(deg.)

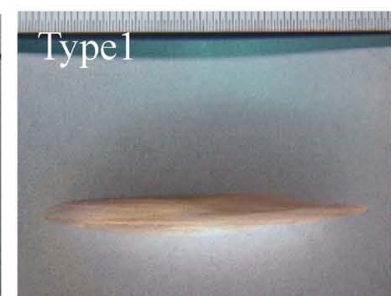

10(deg.)

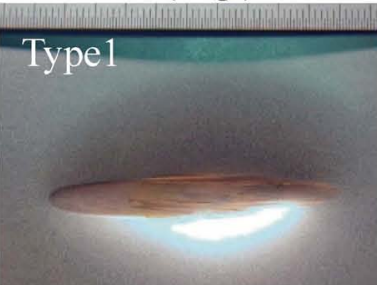

23(deg.)

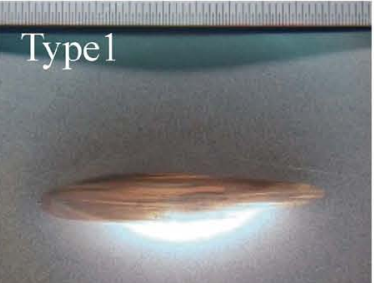

25(deg.)

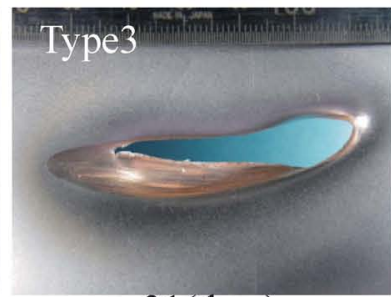

31(deg.)

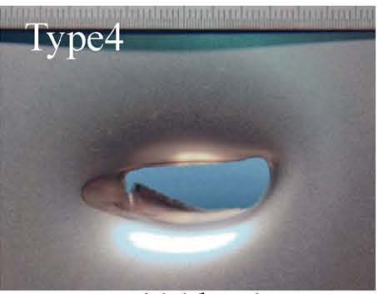

41(deg.)

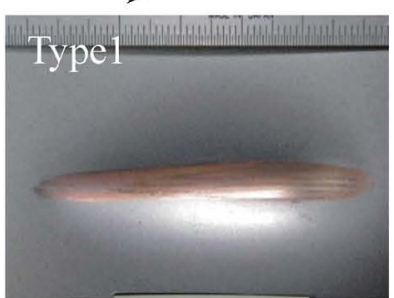

11(deg.)

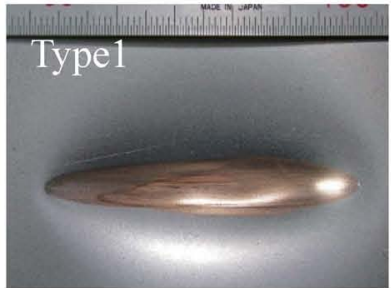

20(deg.)

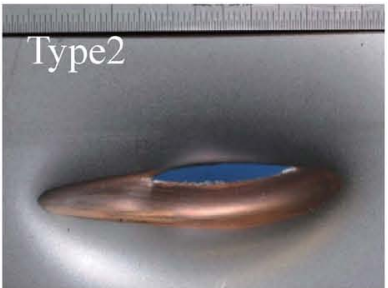

22(deg.)

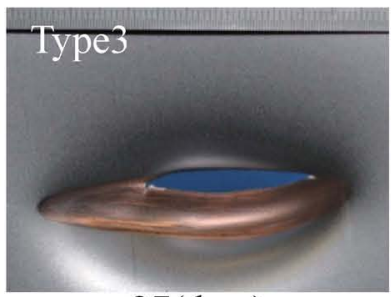

27(deg.)

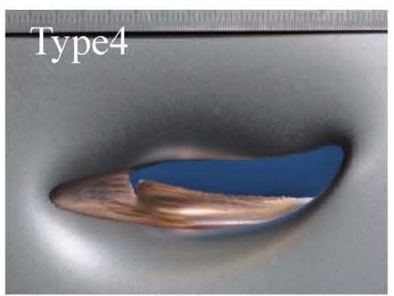

28(deg.)

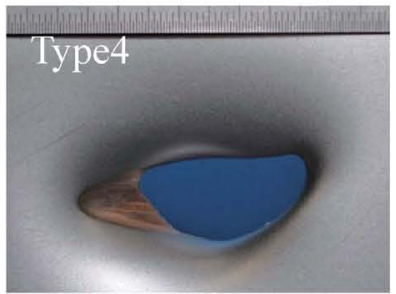

33(deg.)

(g) $9 \mathrm{~mm}$ Luger (FMC)

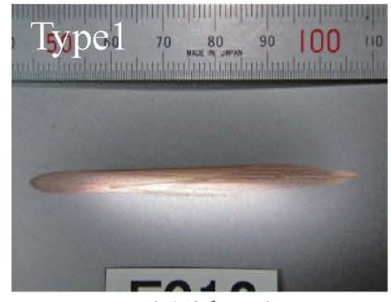

11(deg.)

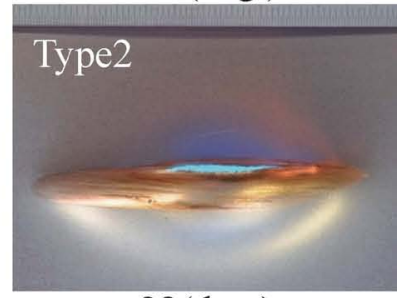

22(deg.)

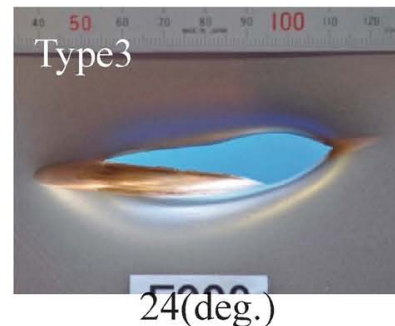

24(đêg.)

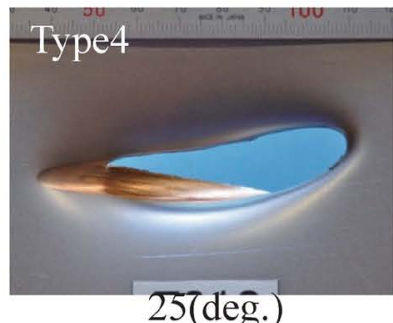

$25(\mathrm{de} \overline{\mathrm{g}}$.)

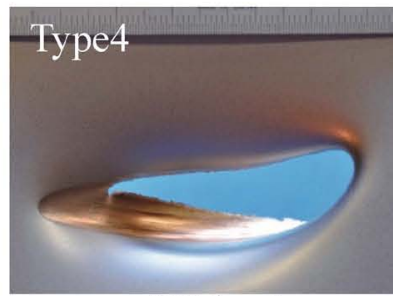

33(deg.)

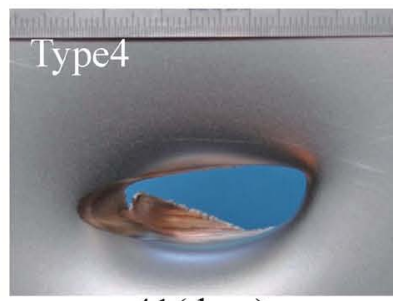

41(deg.)

(h) 45 AUTO. (FMC)

(e) 38 SPL. (FMC) S\&W

(f) 38 SPL. (FMC) Squires Bingham

Fig. 4 Deformation of the thin steel plate after impact of a jacketed bullet, (e)-(h) 


\section{Trajectory of bullet}

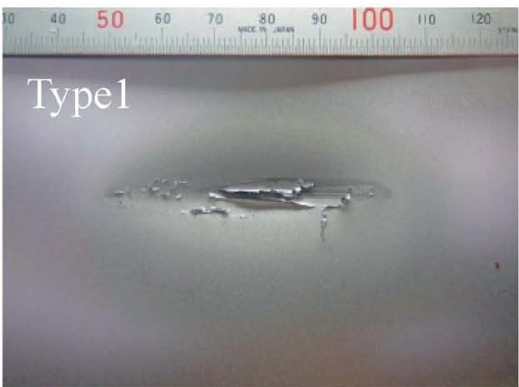

10(deg.)

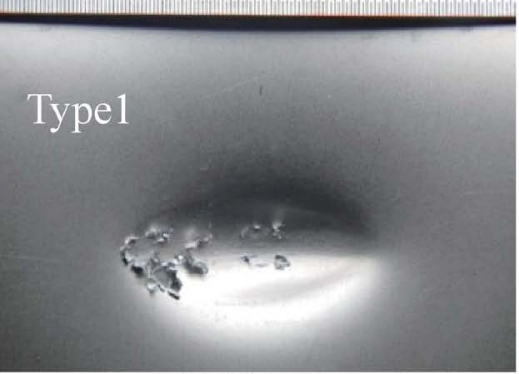

41(deg.)

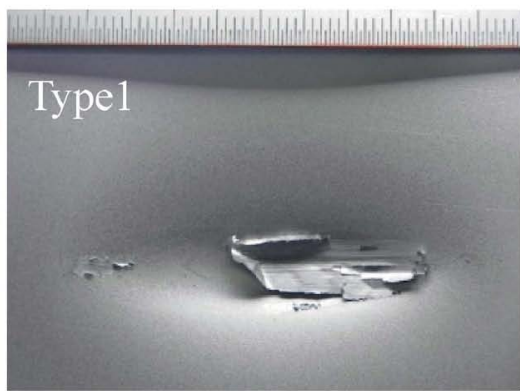

22(deg.)

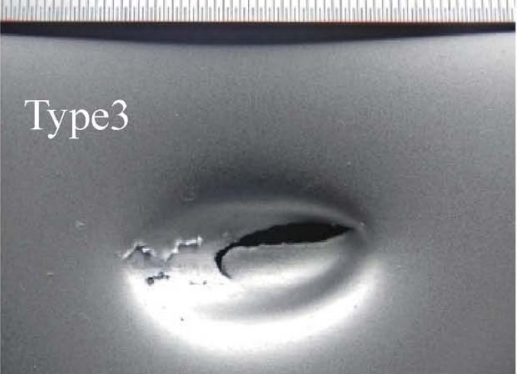

51(deg.)

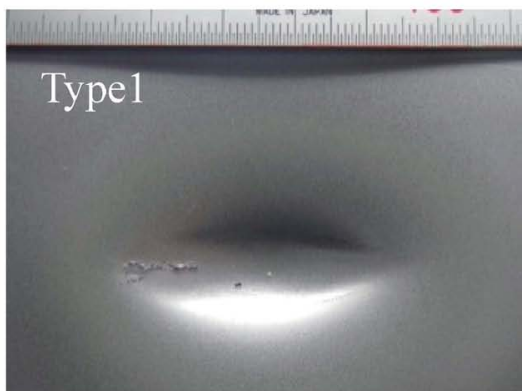

$31(\mathrm{deg}$.

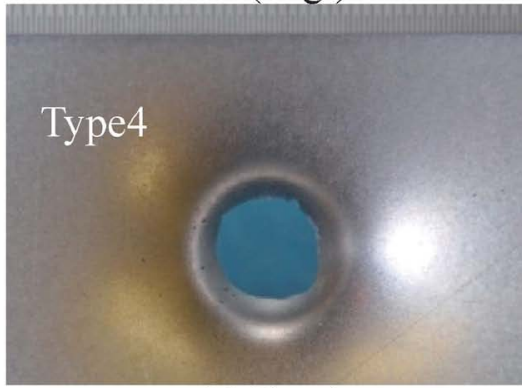

90(deg.)

Fig. 5 Deformation of the thin steel plate after impact of a lead bullet., 38 SPL., (S\&W, LRN).

た.

なお，Fig. 5 の硬鉛弾における薄鋼板の変形形態 に示すとおり，硬鉛弾によって形成された亀裂につ いては，亀裂が接触部側端で形成されていないた め, 発射弾丸の旋回方向による影響が小さいと考え られた．この原因としては，硬鉛弾が被甲弾に比べ 軟らかいことが考えられた。

2. 跳弾痕と発射弾丸の運動エネルギー $E$, 入射角 $\theta_{\mathrm{i}}$ との関係

（1）発射弾丸の運動エネルギー $E$ と跳弾痕との関 係

発射弾丸の運動エネルギー $E$ に対する跳弾痕の 評価には，試射試験結果の Type 1, 2 を用いた。

Type 3 については，亀裂の開口により，寸法が大 きく評価されてしまうため, 跳弾痕の評価から除外 した.

跳弾痕の寸法は, Fig. 6 に示すと抢り，跳弾痕を 楕円状で近似し，長軸方向の長さを $L$, 短軸方向の 長さを $W$ とした。

Fig. 7 に発射弾丸の運動エネルギー $E$ と跳弾痕の 長軸方向の長さ $L$ との関係を示す．跳弾痕の長軸

\section{Trajectory of bullet}

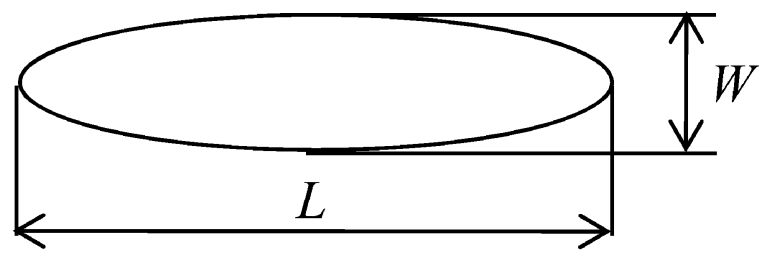

The length in the longitudinally direction, $L$ The width in the transverse direction, $W$

Fig. 6 Schematic illustration of the ricochet mark.

方向の長さ $L$ は, 運動エネルギー $E$ に比例して増 加する傾向が見られた。 また， 380 AUTO. および 38 SPL. を除くと, 跳弾痕の長軸方向の長さ $L$ は, 実包の種類間でほぼ独立していた。

Fig. 8 に発射弾丸の運動エネルギー $E$ と跳弾痕の 短軸方向の長さ $W$ との関係を示す. 跳弾痕の短軸 方向の長さ $W$ は, 実包の種類に関係なく大きくば らついており，両者の関係に顕著な傾向は見られな 
a): SB: Squires Bingham

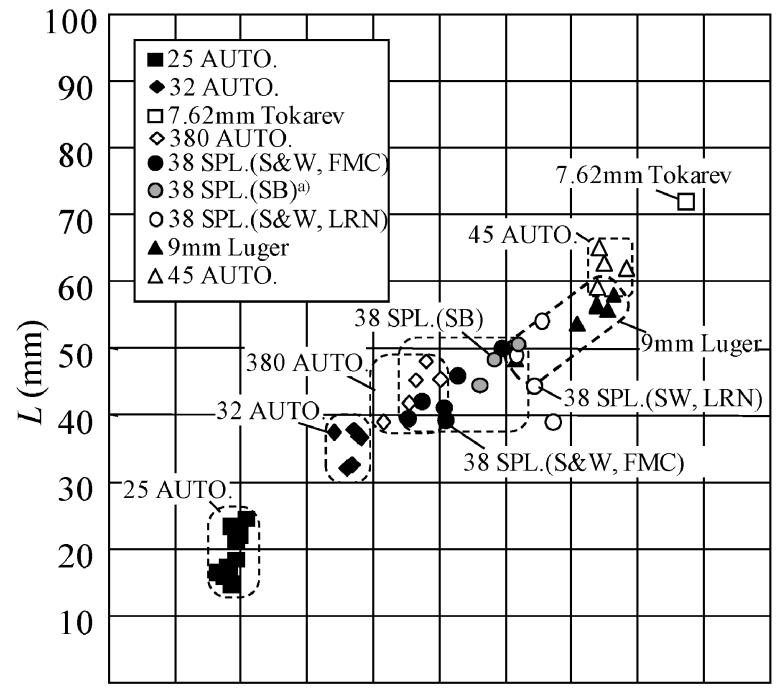

$0 \quad 50 \quad 100150200250300350400450500$ $E(\mathrm{~J})$

Fig. 7 The relationship between the length of the ricochet mark in the longitudinally direction, $L$ and the kinetic energy of the bullet, $E$.

a): SB: Squires Bingham

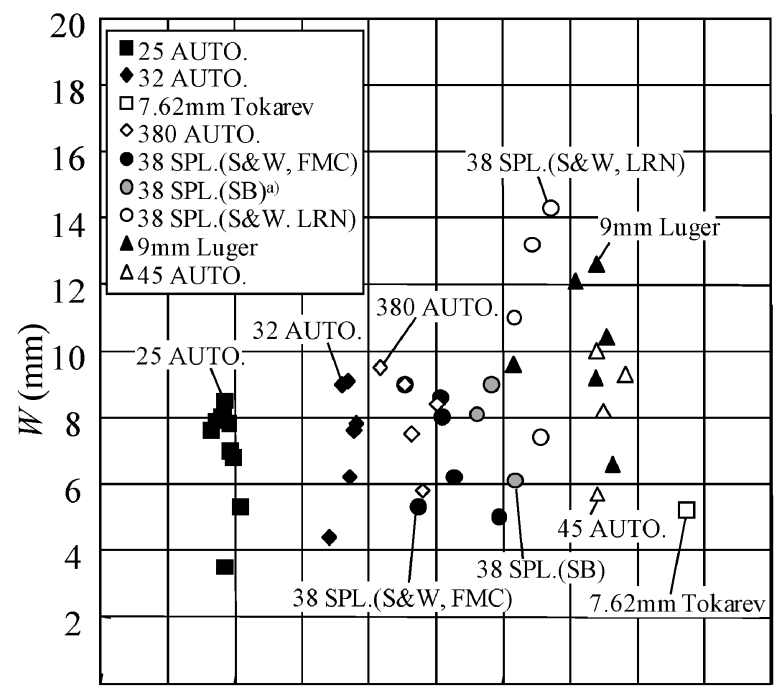

$0 \quad 50 \quad 100150200250300350400450500$ $E(\mathrm{~J})$

Fig. 8 The relationship between the width of the ricochet mark in the transverse direction, $W$ and the kinetic energy of the bullet, $E$. a): SB: Squires Bingham

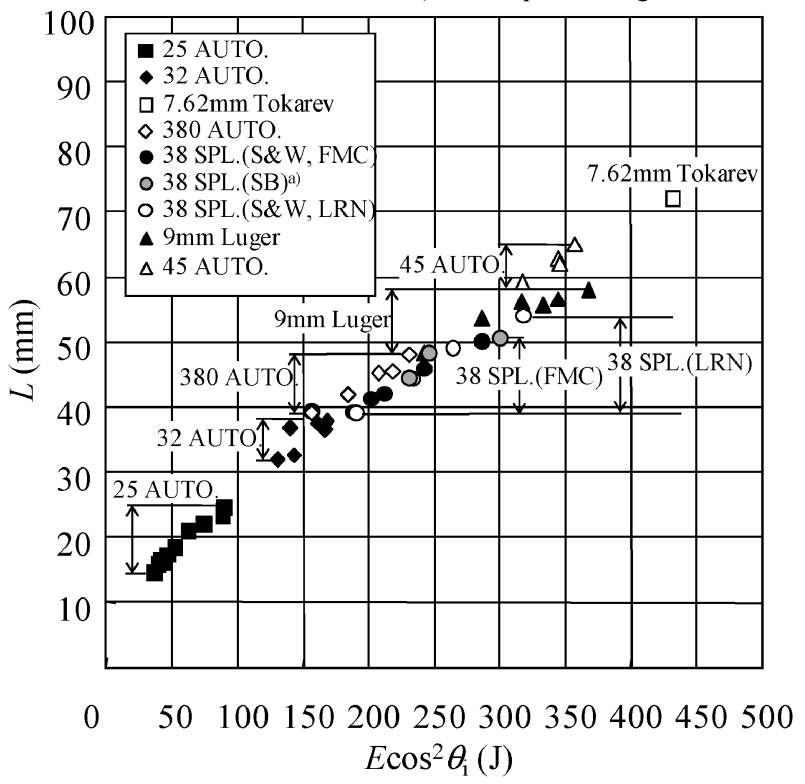

Fig. 9 The relationship between the length of the ricochet mark in the longitudinally direction, $L$ and the kinetic energy of the horizontal component of the bullet velocity, $E \cos ^{2} \theta_{\mathrm{i}}$.

かった.

（2）水平抢よび垂直速度成分に打ける発射弾丸の 運動エネルギー $E \cos ^{2} \theta_{\mathrm{i}}, E \sin ^{2} \theta_{\mathrm{i}}$ と跳弾痕との 関係

発射弾丸の運動エネルギー $E$ 抢よび入射角 $\theta_{\mathrm{i}}$ が 跳弾痕の寸法に及ぼす影響を調べるために，発射弾 丸の速度を，薄鋼板に対する水平方向の速度成分お よび垂直方向の速度成分に分解し，それぞれの運動 エネルギー $E \cos ^{2} \theta_{\mathrm{i}}, E \sin ^{2} \theta_{\mathrm{i}}$ を求めた。

Fig. 9に水平方向の速度成分から求めた発射弾丸 の運動エネルギー $E \cos ^{2} \theta_{\mathrm{i}}$ と跳弾痕の長軸方向の長 さ $L$ との関係を示す. Fig. 9 の結果には, Fig. 7 の 発射弾丸の運動エネルギー $E$ と跳弾痕の長軸方向 の長さ $L$ との関係に比べ，より強い相関が見られ たため, 跳弾痕の長軸方向の長さ $L$ は, 発射弾丸 の運動エネルギー $E$ および入射角 $\theta_{\mathrm{i}}$ に依存してい ると考えられた。 また，Fig. 7 と同様， 380 AUTO. および38 SPL. を除くと, 跳弾痕の長軸方向の長さ $L$ は，実包の種類間でほぼ独立していた。

Fig. 10に垂直方向の速度成分から求めた運動工 ネルギー $E \sin ^{2} \theta_{\mathrm{i}}$ と跳弾痕の短軸方向の長さ $W$ との 
関係を示す. Fig. 10の結果には, Fig. 8 の発射弾丸 の運動エネルギー $E$ と跳弾痕の短軸方向の長さ $W$ との関係に比べ，相関が見られた.

\section{3. 入射角 $\theta_{\mathrm{i}}$ 亡反射角 $\theta_{\mathrm{r}}$ 之の関係}

Fig. 11に試射試験結果 Type 1, 2 における入射角 $\theta_{\mathrm{i}}$ と反射角 $\theta_{\mathrm{r}}$ との関係を示す。 $7.62 \mathrm{~mm}$ Tokarev で唯一 Type 1 に分類される跳弾が見られた入射角 $\theta_{\mathrm{i}} \approx 6^{\circ}$ に打ける反射角 $\theta_{\mathrm{r}}$ は，ほぼ水平方向 $\left(\theta_{\mathrm{r}} \approx\right.$ $0^{\circ}$ ）であった，それ以外の実包については，入射角 $\theta_{\mathrm{i}}$ と反射角 $\theta_{\mathrm{r}}$ との間に，概ね 2 対 1 の傾向が見ら れた。

鋼板における跳弾に関してこれまで行われてきた 研究では，跳弾によって鋼板が変形しない厚い鋼板 の場合，反射角 $\theta_{\mathrm{r}}$ は，入射角 $\theta_{\mathrm{i}}$ によらず鋼板に対 してほぼ水平になり2,6,13-15)，跳弾によって鋼板が 変形する薄鋼板の場合，反射角 $\theta_{\mathrm{r}}$ は，水平より大 きくなる2,13)ことが報告されている，本研究におけ る $1.2 \mathrm{~mm}$ 厚の薄鋼板の結果は，これまで報告され てきた薄鋼板と同様の結果と判断された.

4. 跳弾痕を用いた発射弾丸の実包の種類, 入射角 $\theta_{\mathrm{i}}$ および反射角 $\theta_{\mathrm{r}}$ の推定方法について

本試験結果を基に，発砲現場で発見された跳弾痕 から発射弾丸の実包の種類，入射角 $\theta_{\mathrm{i}}$ および反射 角 $\theta_{\mathrm{r}}$ の推定方法について提案する. 提案する推定 方法は，被射体となる鋼板の厚さが $1.2 \mathrm{~mm}$ の薄鋼 板であり, 発射弾丸が実包本来の威力を有する被甲 弾であることを前提条件としている.

(1) Fig. 3〜Fig. 5 の薄鋼板の変形形態に示すとお り，跳弾痕には，発射弾丸の表面部が固着する ため，跳弾痕表面の固着した箇所から，発射弾 丸の材質を簡便に推定できると考えられた.

（2） Fig. 7 の発射弾丸の運動エネルギー $E$ と跳弾 痕の長軸方向の長さ $L$ との関係および Fig. 9 の 水平方向の速度成分から求めた発射弾丸の運動 エネルギー $E \cos ^{2} \theta_{\mathrm{i}}$ と跳弾痕の長軸方向の長さ $L$ との関係に示すと抢り，Type 1, 2 に分類され る跳弾痕の長軸方向の長さ $L$ は, 380 AUTO. および38 SPL.を除き，実包間でほぼ独立して いる.したがって, 跳弾痕の長軸方向の長さ $L$ から, 発射弾丸の運動エネルギー $E$ 抢よび水平 方向速度成分から求めた運動エネルギー $E \cos ^{2} \theta_{\mathrm{i}}$ a): SB: Squires Bingham

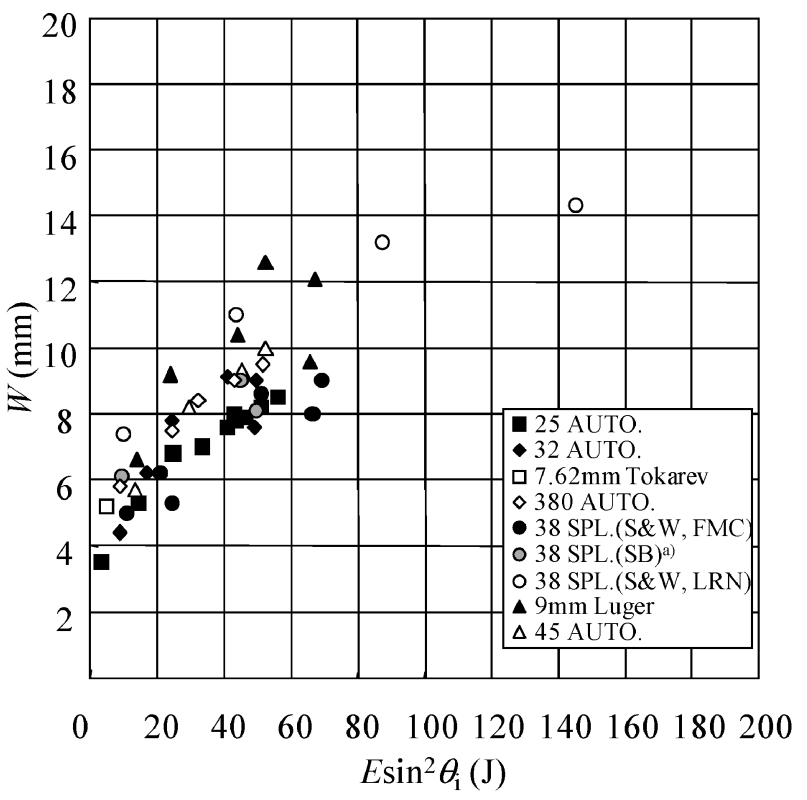

Fig. 10 The relationship between the width of the ricochet mark in the transverse direction, $W$ and the kinetic energy of the vertical component of the bullet velocity, $E \sin ^{2} \theta_{\mathrm{i}}$.

a): SB: Squires Bingham

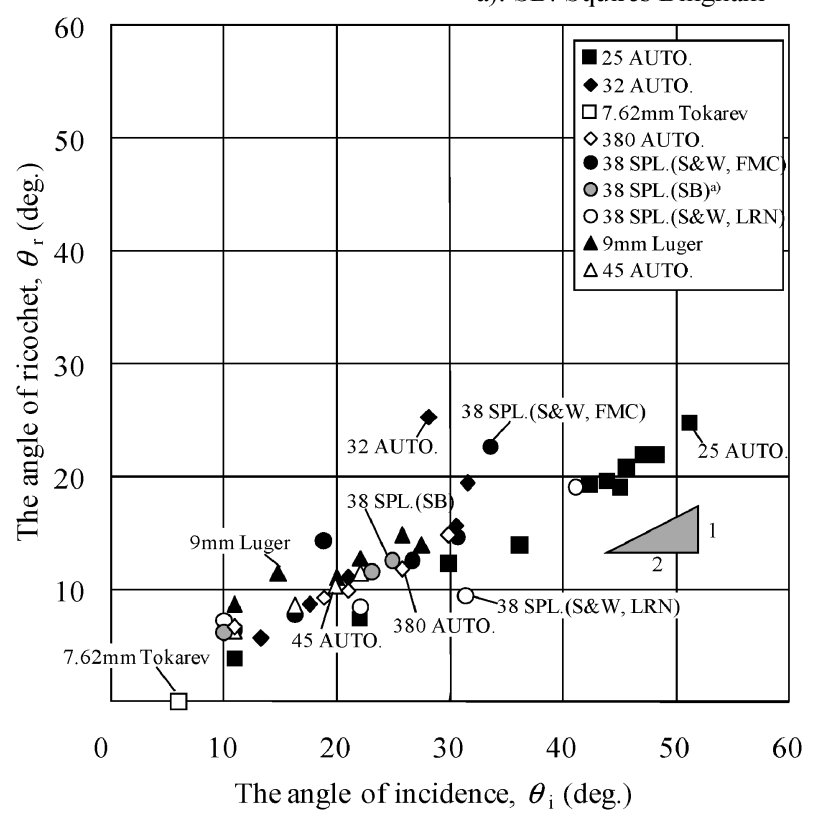

Fig. 11 The relationship between the angle of incidence, $\theta_{\mathrm{i}}$ and the angle of ricochet, $\theta_{\mathrm{r}}$. 
を求めることで, 発射弾丸の実包の種類および 入射角 $\theta_{\mathrm{i}}$ を推定できる場合があると考えられ た。

なお, 跳弾痕の長軸方向の長さ $L$ が重複した 380 AUTO. と38 SPL. とを区別するためには， 発砲現場に抢ける打ち殼薬きょうの遺留の有無 などで，犯行に使用された拳銃が自動装てん式 拳銃（380 AUTO.）加回転弾倉式拳銃（38 SPL.）かを判断する必要があると考えられた。

(3) Fig. 11 の入射角 $\theta_{\mathrm{i}}$ と反射角 $\theta_{\mathrm{r}}$ との関係に示す と抢り，反射角 $\theta_{\mathrm{r}}$ については，4.(2)で求めた 入射角 $\theta_{\mathrm{i}}$ を $1 / 2$ にすることで推定できると考え られた。

なお， $7.62 \mathrm{~mm}$ Tokarevによる跳弾について は, 跳弾した弾丸が薄鋼板に対してほぼ水平方 向に飛翔すると考えられた．

（4）その他にも, Fig. 3, 4 の被甲弾における薄鋼 板の変形形態に示すとおり, 跳弾痕が Type 2, 3 に分類される場合，薄鋼板と発射弾丸との接触 部側端に形成された亀裂の位置から, 発射銃器 の腔旋方向を推定することができると考えられ た。

以上の方法を用いることで, 跳弾痕から発射弾丸 の実包の種類や入射角 $\theta_{\mathrm{i}}$, 反射角 $\theta_{\mathrm{r}}$ を推定するこ とができ,さらに, 弾道の推定結果を用いて, 射撃 位置の推定や跳弾した発射弾丸の捜索に貢献できる と考えられた。

\section{結 語}

本研究では, 発射弾丸が鉄鋼製品で跳弾した発砲 事件に拈いて, 発射弾丸の実包の種類や弾道を推定 するために，発砲事件でよく使用される実包抒よび 一般的に使用される薄鋼板を用いて跳弾をともなう 試射試験を行い，形成された跳弾痕から発射弾丸の 実包の種類や弾道を推定する方法について研究を行 った. その結果, 被甲弾が厚さ $1.2 \mathrm{~mm}$ の薄鋼板で 跳弾した場合では, 跳弾痕から発射弾丸の実包の種 類および弾道について推定できることを明らかにし た。結果を下記に示す。

（1）跳弾痕の表面には, 発射弾丸の表面部が固着 するため，その固着した箇所から，発射弾丸の
材質を簡便に推定できる.

(2) $1.2 \mathrm{~mm}$ の薄鋼板では, 跳弾痕の長軸方向の 長さ $L$ から発射弾丸の運動エネルギー $E$ 抢よび 水平方向速度成分から求めた運動エネルギー $E \cos ^{2} \theta_{\mathrm{i}}$ を求めることで, 発射弾丸の実包の種類 および入射角 $\theta_{\mathrm{i}}$ を推定することができる.

（3） 入射角 $\theta_{\mathrm{i}}$ と反射角 $\theta_{\mathrm{r}}$ との関係には，概ね 2 対 1 の傾向が見られた.

（4）被甲弾によって形成された跳弾痕に亀裂が形 成された場合, その位置が薄鋼板と発射弾丸と の接触部側端であれば，亀裂の位置から拳銃の 腔旋方向を推定できる.

\section{文 献}

1) Federal Bureau of Investigation: Bouncing Bullet, FBI Law Enforcement Bulletin, 38, pp. 19 (1969).

2) Jauhari, M.: Bullet Ricochet from Metal Plates. J. Criminal Law, Criminology and Police Sci., 60, 3, 387-394 (1969).

3) Jauhari, M.: Mathematical Model for Bullet Ricochet. J. Criminal Law, Criminology and Police Sci., 61, 3, 469-473 (1970).

4 ) Jauhari, M.: Approximate Relationship Between the Angles of Incidence and Ricochet for Practical Application in the Field of Forensic Science. J. Criminal Law, Criminology and Police Sci., 62, 122-125 (1970).

5) McConnell, M. P., Triplett, G. M. and Rowe, W. F.: A Study of Shotgun Pellet Ricochet. J. Forensic Sci., 26, 4, 699-709 (1981).

6) Hartline, P. C., Abraham, G. and Rowe, W. F.: A Study of Shotgun Ricochet from Steel Surfaces. J. Forensic Sci., 27, 3, 506-512 (1982).

7) Burke, T. W., Griffin, R. and Rowe, W. F.: Bullet Ricochet from Concrete Surfaces. J. Police Sci., 16, 264-267 (1988).

8) Jordan, G. E., Bratton, D. D., Donahue, H. C. H. and Rowe, W. F.: Bullet Ricochet from Gypsum Wallboard. J. Forensic Sci., 33, 6, 1477-1482 (1988). 
9) Burke, T. W. and Rowe, W. F.: Bullet Ricochet: A Comprehensive Review. J. Forensic Sci., 37, 5, 1254-1260 (1992).

10) Gold, R. E. and Schecter, B.: Ricochet Dynamics for the Nine Millimeter Parabellum Bullet. $J$. Forensic Sci., 37, 1, 90-98 (1992).

11) Mitosinka, G. T.: Technique for Determining and Illustrating the Trajectory of Bullets. $J$. Forensic Sci. Soc., 11, 55-61 (1971).

12) Janssen, D. W. and Levine, R. T.: Bullet Ricochet from Automobile Ceilings. J. Forensic
Sci., 27, 1, 209-212 (1982).

13）北村生夫, 財津 博 : 発射弾丸の鋼板反跳. 貫通後の変形挙動．科警研報告，46, 2, 65-77 (1993).

14) Houlden, M.: The Distribution of Energy among Fragments of Ricocheting Pistol Bullets. $J$. Forensic Sci. Soc., 34, 29-35 (1994).

15) Haag, M. G. and Haag, L. C.: Shooting Incident Reconstruction, Second Edition, pp. 143-174, Elsevier Inc. (2011). 